\title{
Some Considerations concerning the Mass Movements and Geological Conditions in Japan マスムーブメントの地質条件に関する考察
}

\author{
Takahiro TERAKAWA* and Shoichi NiSHIDA** \\ 寺 俊浩, 西田彰一
}

\begin{abstract}
<要 旨 $>$
日本のような島孤にみられる地すべり運動像とチェコスロバキアのような安定大陸の地すべり運動像との間には大 きな差異がある。これは一義的には岩体自体のひずみ像の量的相違によるものと考える。一方，巨大な岩塊の滑動と いらマスムーブメントを保持するためには，その場所の基盤を構成する岩石の物理的・化学的性質が地すべり運動像 に深い関係がある点をここに新しく指摘した。換言すれば地すべり面の粘土が滑剤となり，その上にのっている岩塊 をすべりやすくするか否かが運動像の形態に大きく影響する。すなわち，このタイプのマスムーブメントが成り立つ ためには, 地山から離脱する岩塊内部の地質分離面の分布と基盤をつくる泥岩の物性と化学的性質との相互作用によ るものであることを新潟県下の代表的例をあげその発生機構を説明した。
\end{abstract}

\begin{abstract}
The present paper discusses the substantial difference between the kinematic picture of the landslides in Japan and that of the mass movements in Czechoslovakia, from the viewpoints of geotectonics and engineering geology. A representative kinematic picture of the landslides in Japan which is typical of arcuate islands, is largely different from the one in a platform or a stable land like Czechoslovakia. The difference can be ascribed partly to the climatic condition and partly to the quantity of strain picture of the rock mass itself. Especially the latter factor would be reflected clearly in the real aspect of the mass movements. On the other hand, it should be noted that the physical and chemical properties of the basement rocks are intimately related to the maintenance and continuance of a mass movement in that place, such as the gliding of huge blocks. In other words, whether or not the clay of the slip surface acts as a lubricant to help sliding of the overlying blocks will largely influence the form of the kinematic picture. The writers would like to propose, therefore, that a mass movement of this type is a result of the interaction of the distribution of discrete surfaces in the blocks breaking away from the natural ground and the lithology of the mudstone that constitutes the basement. As an additional remark the writers suggest that in view of the geological conditions, particularly the geotectonic history, of the Japanese island arc, a mass movement of the Czechoslovakia-type can develop in Japan according to the geologic structure and the rock factors, and the cause of the movement can be explained geologically and geotechnically.
\end{abstract}

\section{Introduction}

The writers had an opportunity of attending the Symposium on Landslides and Other Mass Movements, which was held in Prague on September 15 and 16, 1979, under the auspices of the International Association of Engineering Geology (IAEG). After the Symposium was over, the 
writers visited the Carpathian region to observe several known localities of landslides. Through this excursion the writers were able to perceive actual circumstances of landslides in Czechoslovakia. In the present paper the writers, making good use of the above experience, discuss the substantial difference between the kinematic picture of the landslides in Japan and that in Czechoslovakia, and give some considerations on the relationship between the Czechoslovakia-type mass movements in Japan and tectonic provinces, as well as on the physico-chemical properties of basement rocks that rule the kinematic picture of landslide.

\section{Landslides and geological conditions of Czechoslovakia}

Geologically Czechoslovakia is much different from Japan. The basement of Czechoslovakia is composed of Pre-Cambrian rocks, overlain by the Paleozoic, Mesozoic and Cainozoic formations that are developed in an almost complete stratigraphic sequence. The Bohemian region, in particular, is a platform, and so the widely distributed Cretaceous beds, for example, are affected very little by folding and the degree of consolidation of rocks is low.

From the viewpoint of geotectonic history, Czechoslovakia can be divided into two distinct tectonic provinces; one is the Bohemian massif and the other is the Carpathians. The geological conditions of these two tectonic provinces are fairly different in both quality and quantity. Accordingly, the kinematic picture of the landslides would reflect the geological conditions of each province, resulting in the respectively characteristic landslides and mass movements. It is considered, however, that essential differences, if any, between the two provinces are not very large, except for the Carpathian mountain range. But the landslides in Japan are intrinsically different from those in Czechoslovakia. This is probably due to the character of the tectonic unit, Japan being arcuate islands. Geology of the Bohemian region is older in age than the Carpathian region, as expressed well by the topography and the lithology. After the Caledonian orogeny the Bohemian region became a platform, and with the progress of planation the present peneplaned topography has been formed. In the course of this geotectonic history, the Cretaceous beds among the geologic formations later than the Caledonian orogeny were deposited in a vast basin, and their degree of consolidation is lower and the strain smaller than in the Japanese Cretaceous beds. Such geological conditions would account for the fact that landslides in the Bohemian region are concentrated in the Upper Cretaceous beds.

The Carpathian region, on the other hand, suffered the Variscan orogeny and the Alpine orog. eny, and after the Variscan orogeny the central area of the region turned into a stable land, excepting the Carpathian mountain range. Thus, in the stress field condition this region is fundamentally different from arcuate islands like Japan which has been subjected to very young crustal disturbances.

Geotectonically the Carpathian region is divided as follows: (1) Region of the core-mountains, (2) Region of the Carpathian Flysch, (3) Region of the Neogene volcanic rocks, (4) Region of the Neogene tectonic depression.

The geological conditions of regions

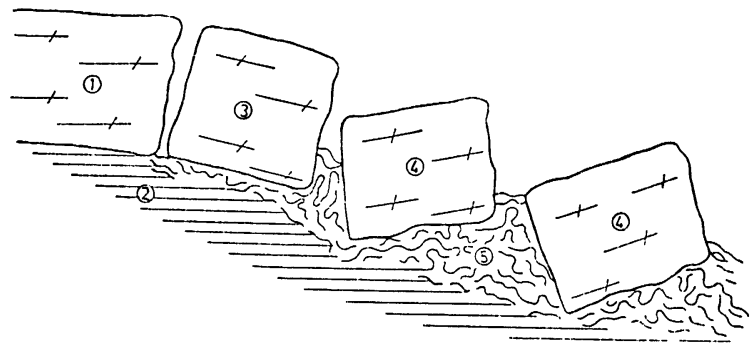

Fig. 1. Schema of the tormation of block-type landslides. (1) Upper layer or hard brittle rocks; (2) Lower layer of soft plastic rock; (3) Rock block, separated from the upper layer-start of a landslide cycle; (4) Slide rock blocks, which have underzone lineartranslations and rotational movement; (5) Deformed plastic masses fo the lower layer. (taken from Kamenv et al. 1977). 


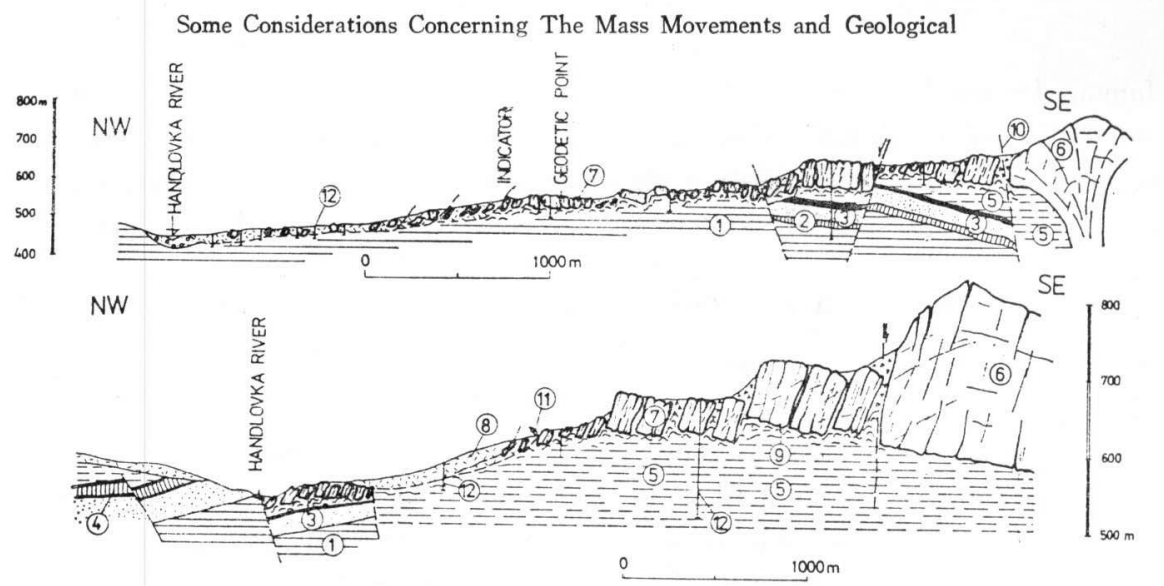

Fig. 2. Geological cross-sections through Handlova basin.

(1) Clayey and marly shales, sandstones-Flysch complex-(Palaeogene); (2) Clays (Burdigalian); (3) Psammitic and psefitic tuffs; (4) Coal bearing series; (5) Claystones (3) (5)-Tortonian); (6) Andesities agglomerate tuffs(Sarmatian); (7) Block type deformations; (8) Landslides; (9) Creeping zones; (10) Faults; (11) Springs; (12) Boreholes. (taken from Otepka 1977)

(2) and (3) are intimately related to the landslides in Czechoslovakia. The Carpathian Flysch is distributed around the region of the core -mountains exposed in the central part of the Carpathian region. It consists of rhythmically alternating sandstone and mudstone of Oligocene to Miocene age. Many of the landslides in the Carpathian region occurred in this Flysch. It may be attributable to the physical properties of rocks and the nature of strain. The kinematic picture of landslides of this type is typical of mass movement, and the style of the

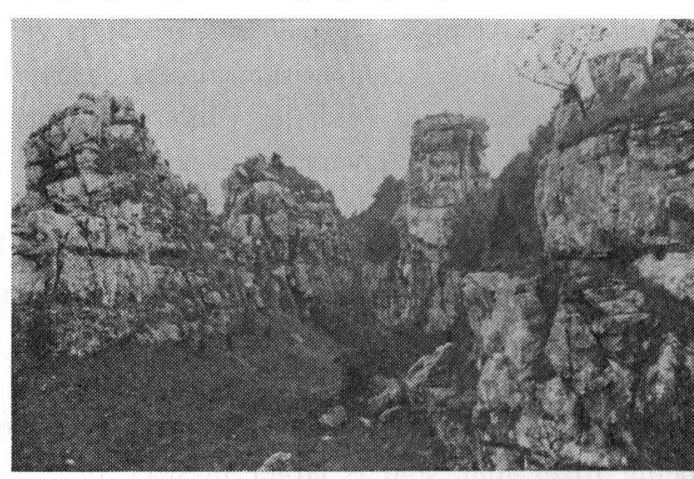

Fig. 3. Block-field on Drevenik in eastern Slovakia. The blocks of hard travertine tilted and shifted on the soft Flysch substratum (photo by Terakawa).

movement is governed by two geological conditions, the Flysch and the covering volcanics. In short, the movement is a gliding motion at the slip surface that came into existence along a creep zone formed between the volcanic rock mass and the underlying mudstone. The kinematic picture of the mass movements in the Carpathian region is explained here, by citing the instance of the Handlová landslides which are of the largest scale in Czechoslovakia. The geology of the Handlová basin is composed of the following strata in ascending stratigraphical order: 1) clayey and marly shales, sandstones-Flysch complex, 2) clays, 3) psammitic and psephitic tuffs, 4) coalbearing series, 5) claystones, 6) andesites, agglomerate tuffs, and also volcanics.

As for their geologic age, 1) is Paleogene, 2) is Burdigalian, 3) 5) are Tortonian, and 6) is Sarmatian. The cause of the Handlová landslides is illustrated as follows: In the uppermost part of the claystones of 5), namely between the claystones and the volcanics, a water-bearing layer is formed, which results in the birth of a creep zone there. Then, the volcanics break vertically into rectangular blocks which begin to glide down the dip. The blocks are $40 \sim 100 \mathrm{~m}$ long. The breakaway of blocks from the volcanics depends on the rock's discrete surfaces, such as joints or minor faults. As mentioned above, the blocks would glide down the slip surface along the creep zone that was formed in the underlying plastic Tertiary claystones, and would migrate in the manner of bogging down. 
The famous Drevenik landslides of Czechoslovakia present a kinematic picture quite identical with that of the Handlová landslides, the only difference being that the Paleogene Flysch in Drevenik is covered by travertine. In both cases, the joints and minor faults formed in the veneer rock are controled by the fracture system of the Flysch constituting the basement.

\section{Kinematic picture and mechanism of mass movement}

The origin and development of mass movements in the Handlova basin of Czechoslovakia have been studied, especially from the viewpoint of rock properties. On the relation between the character of landslides and the physical properties of rocks, a more detailed analysis has been reported. According to the analysis, in the area of the Handlova landslides the Tertiary system overlain by the volcanics is a Paleogene formation in some places and a Neogene formation in other places, and the mudstones constituting the two formations are considerably different in physical properties. The same aspect is noticed in the physical properties of Tertiary rocks in the KordfkyKráliky landslide area of the Handlová basin. In both of the two landslide areas, the Paleogene clayey shales are smaller than the Neogene claystones in the values of density, natural moisture content, plasticity index, consistency, porosity and clay activity. Especially the value of clay activity is 1.02 in the former whereas it is very high in the latter, amounting to 3.04.

The clay mineral composition also is clearly different between the two, since illite is dominant in the Paleogene clayey shales while montmorillonite is dominant in the Neogene claystones.

A very interesting phenomenon is recognized by comparing the kinematic picture of landslides in the area of Paleogene basement with that in the area of Neogene basement. In the case where the basement is composed of Paleogene rocks, the landslides are of small dimensions and their kinematic picture is planar or frontal, less stream-like. The shear plane form would glide in a rotationalplanar style. Thickness of the mass is small, ranging between $5 \mathrm{~m}$ and $15 \mathrm{~m}$. In the case of the Neogene basement, on the contrary, the landslides occur more extensively. They are stream -like landslides with a complex system of differential shear planes. The mass is generally thick, being 10 to $40 \mathrm{~m}$, and is larger in size. In comparison with the case where the basement is composed of Paleogene shale, the landslides in the area of the Neogene basement seem to suggest that the character of the basement rocks has its effect, though indirectly, on the kinematic picture of the landslides, considering from a geotechnical viewpoint.

In the explanation given above, the instances of Czechoslovakia have been cited. It is inferred that one of the causative factors of landslide is the physico-chemical character of the basement rocks which would be reflected in the kinematic picture of the landslide. In short, the mode of landslide occurrence varies with the geological age and the clay mineral composition of the basement rocks. To explain the situation further, a creep zone is formed along the slip surface in the uppermost part of the plastic rock mass covered by the solid rock mass, as mentioned earlier. And in this creep zone the argillization of the basement rock takes place and the landslide clay is produced, thus creating what is called a lubricating layer to cause the gliding of the solid rock mass. In this case, whether or not the rock blocks will slide easily along the slip surface depends fundamentally on the nature of the basement mudstone, which is closely related to the dimensions of the blocks, namely the kinematic picture of the landslides. It must be remembered that the mudstone's plasticity index and clay activity are particularly important elements. As observed in the examples of Czechoslo-vakia, there is a very interesting phenomenon that the kinematic picture of the landslides is considerably different between the case of the Paleogene basement and the case of the Neogene basement.

Now, let us inquire into the nature of the solid rock mass resting on the plastic mudstone. A noticeable point in this case is the discrete surface formed in the rock mass itself. It is important to know the scope and the frequency of the fracture system such as joints and minor faults that are developed in the rock mass. Of course, directional trend and regularity of fractures should also 
be taken into consideration. As far as the mass movements observed in the Bohemian region and in the central part of the Carpathian region of Czechoslovakia are concerned, the fractures developed in the rock mass are geotectonic discrete surfaces. It is characteristic that the vertical fractures which account for the blocks show regularity and directivity and their scale is large. In other words, no complex system of fractures is developed, which means that the rock mass was not crushed. These features can be attributed to the tectonomechanical environment serving as a stress field of that region, to which the rock mass wass subjected. In Czechoslovakia with its greater part lying on the stable crust, the amount of strain is by far smaller and the fracture development is much less than the rocks constituting the arcuate islands like Japan. Because of such geological conditions, there ought to be a fairly distinct difference between Czechoslovakia and Japan in the kinematic picture of the landslides.

As has been explained so far, the kinematic picture of mass movements is controled by the two conditions; one is the physicochemical properties of the basement rock which acts as a sliding platform, and the other is the state of fractures in the solid rock mass covering the basement. The writers propose that mass movements are a result of the composite action of these two conditions.

It must be mentioned especially that the Czechoslovakia-type mass movements could occur in Japan if the said two conditions were available sufficiently. The situation will be explained with a concrete example. The typical instance is the Koutanne landslide in the mountainous area between the Umikawa river and the Hayakawa river in Nishikubiki dist-

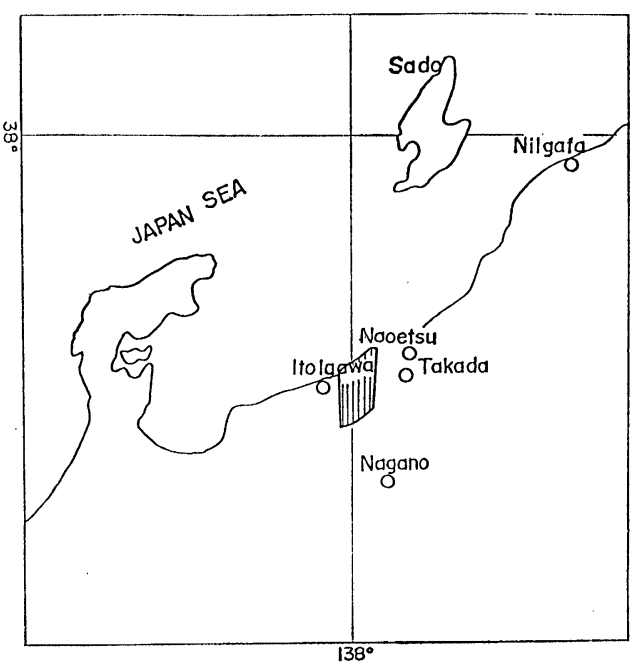

Fig. 4. Index map. Hatched area is the Nishikubiki district, Niigata prefecture.

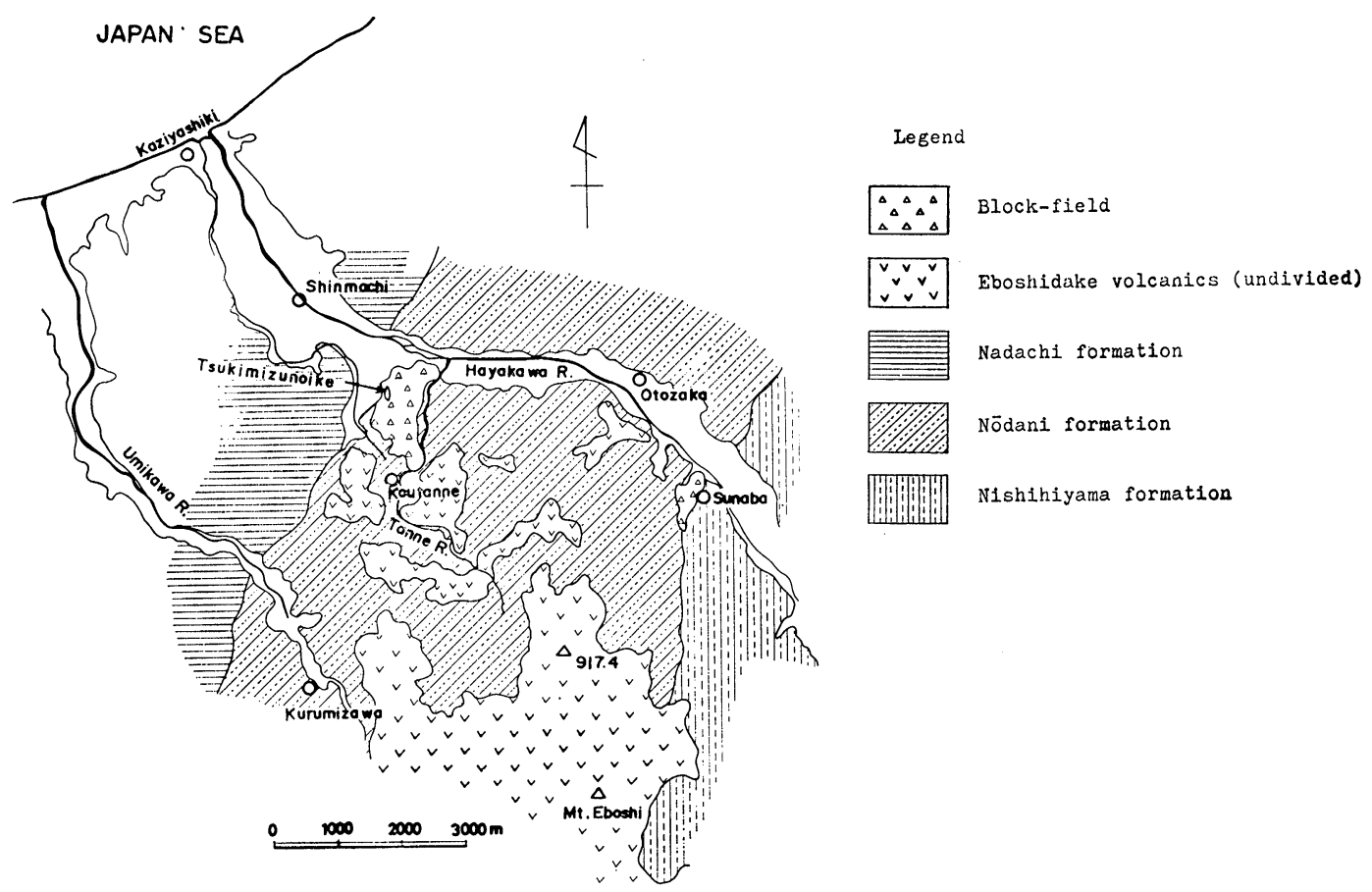

Fig. 5. Geological map of the Tsukimizunoike pond area and its environs. 

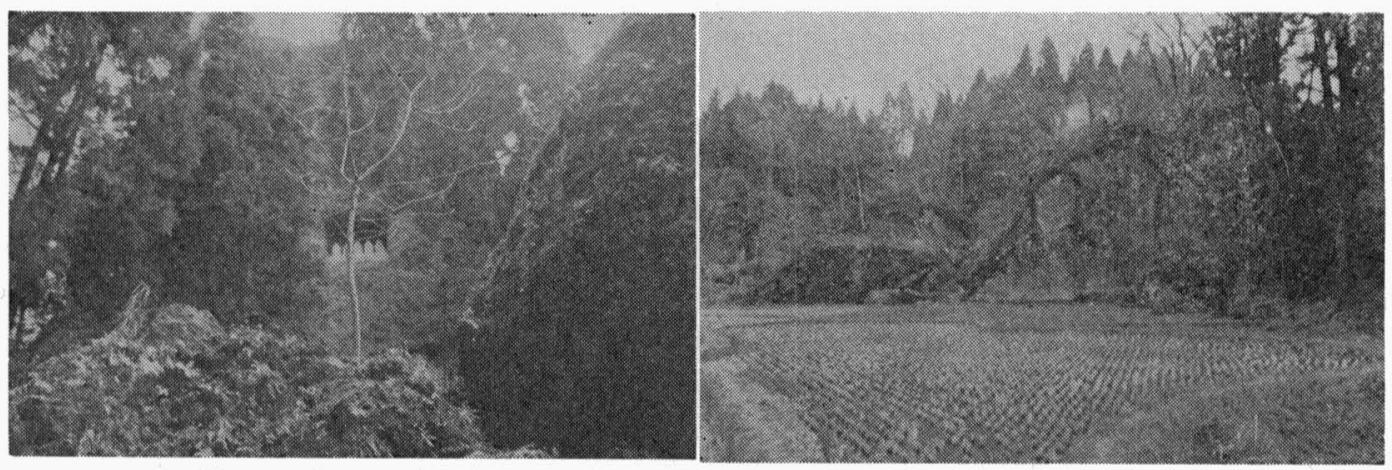

Fig. 6. Photographs sho wing the so-called "block-field" in the Tsukimizunoike pond on the left side area of the Hayakawa river.

rict of Niigata Prefecture. This landslide area is composed of the Neogene Tertiary Nōdani formation (Middle Miocene). The formation consists of alternating beds of mudstone and sandstone, and is widely covered by Quaternary pyroclastics and lava in a distinct clino-unconformable relation. The total thickness is $300 \mathrm{~m}$ or so. The stratigraphic rela tion between the Nōdani formation and the overlying volcanics is worthy of special attention. While the Nödani formation is folded gently, the overlying volcanics are resting horizontally. This fact may provide an important key in considering the mechanism of the kinematic picture of the Koutanne landslide, but this problem will be discussed later.

The basement of the Koutanne landslide area is made up chiefly of Neogene Tertiary mudstone, as mentioned above. In the uppermost part of the mudstone overlain by volcanics, a creep zone was formed along the slip surface, and there are traces that huge blocks breaking away from the solid mass of volcanics have glided down over a considerable distance. On the other hand, it is found that tilted and shifted blocks have

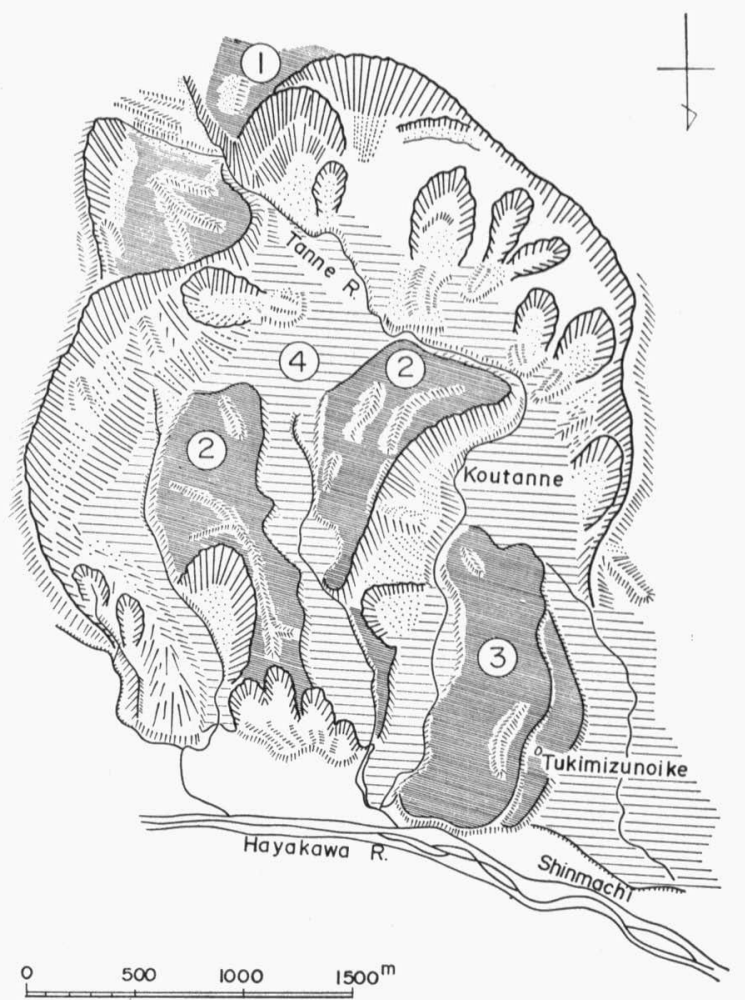

Fig. 7. Idealized diagram of Koutanne landslides. (1) andesite mass; (2) andesite blocks; (3) block-field of andesite mass; (4) Nōdani formation accumulated and formed a so-called block-field in the Tsukimizunoike pond at the margin of the mountains with Mt. Eboshi $(1,450.5 \mathrm{~m})$ as the main peak. Such blocks are observed not only in the Tsukimizunoike pond but also in other places of the foot slope of Mt. Eboshi.

Let us further examine the geological conditions that favor the development of this type of mass movement in this area.

The stratigraphic position of the Nodani formation constituting the basement of the Koutanne landslide area is shown in Table/. Mudstones in different horizons of the respective formations are hereby compared, regarding to their physical properties and clay mineral compositions. Examination of density, natural moisture content and porosity among the various physical properties reveals that the average density (unit weight rt) is $1.72 \mathrm{t} / \mathrm{m}^{3}$ in the Nadachi formation, $2.10 \mathrm{t} / \mathrm{m}^{3}$ in the Nödani formation, $2.50 \mathrm{t} / \mathrm{m}^{3}$ in the Nishihiyama formation and $2.60 \mathrm{t} / \mathrm{m}^{3}$ in the Hiuchiyama form 
Some Considerations Concerning The Mass Movements and Geological

Table 1.

\begin{tabular}{|c|c|c|c|}
\hline \multicolumn{2}{|c|}{ Geological age } & Formation name & Lithology \\
\hline \multicolumn{2}{|c|}{ Quaternary } & Eboshidake volcanics & andestic lavas, basaltic lavas, and their pyroclastics \\
\hline \multirow{6}{*}{$\begin{array}{l}\text { Neogene } \\
\text { Teltiary }\end{array}$} & \multirow{2}{*}{ Pliocene } & Nadachi formation & grey siltstones \\
\hline & & Kawazume formation & alternation of tuffaceous sandstone and shale \\
\hline & \multirow{4}{*}{ Miocene } & Nödani formation uppear & dark grey-black shales \\
\hline & & lower & alternation of sandstone and grey-black shale \\
\hline & & Nishihiyama formation & rhythmic alternation of sandstone and black shale \\
\hline & & Hiuchiyama formation & hard black shales \\
\hline
\end{tabular}

ation. Thus the density is seen to increase toward the lower horizons. The natural moisture content is $30 \%$ in the Nadachi formation, $15 \sim 20 \%$ in the Nodani formation, and the value becomes suddenly smaller in the Nishihiyama formation and the Hiuchiyama formation. As for the porosity, when the Nōdani formation is divided into the upper part and the lower part by lithology, the value around $30 \%$ is found at the boundary between the two parts. The value at the boundary between the Nodani formation and the Nishihiyama formation is $13 \%$ or so. The writers take notice of the relation between the porosity and the clay mineral composition, although it might turn out just a superfluous explanation. Compaction stage and mechanism of changes from soil into rock have been studied by Hedberg (1936), Weller (1959), Burst (1969), and Hoshino \& Inami (197 6 , 1977). Hoshino \& Inami divided the process of compaction into three stages, and on the basis of the texture and physical properties of the mudstone at each stage they set up the order of progress of compaction as follows: (1) viscous compaction stage $\rightarrow$ (2) plastic compaction stage $\rightarrow$ (3) elastic compaction stage.

Belonging to the viscous compaction stage (1), are mostly semiconsolidated rock or soil. In the plastic compaction stage (2), the constituent grains of the rock are brought into perfect contact with one another, and the compaction progresses with deformation and crushing of the mineral grains. Therefore, in comparison with the viscous compaction stage, the stage (2) compaction is dependent on the deformation of framework which results from the conjunction of mineral grains. Hoshino \& Inami have set a boundary between stage (1) and stage (2) at $30 \%$ of porosity. This is of great significance, since the compressive strength increases with decreasing porosity below $30 \%$ while the compressivility becomes rapidly larger when the porosity exceeds $30 \%$. The boundary between the elastic compaction stage and the plastic compaction stage is supposed to lie at about $10 \%$ of porosity. In stage (3), however, authigenic minerals like quartz and other silicate minerals would grow up, resulting in a firmly conjugated texture, and consequently the mudstone comes to have a dynamically stronger elasticity.

In view of the porosity, the boundary between the Nidani formation and the Nishihiyama formation can be set at the value of $13 \%$ as mentioned before. This value roughly agrees with the theoretical value given by Hoshino \& Inami. Judging from the porosity, therefore, it would be reasonable to assume that the upper part of the Nodani formation corresponds to the viscous compaction stage, and the mudstones in the lower part of the Nishihiyama formation or further below are assigned to the elastic compaction stage. Results of the immersion test ${ }^{*}$ and the swelling text, as well as the unconfined compressive strength, are given in Table 2. These tests were made only with the samples from the Nadachi formation and the Nödani formation. In the immersion test, the samples were classified qualitatively into the following four types by their state after immersion. A: original form is retained, B: original form is slightly lost, C: more than $50 \%$ of original form is lost, D: more than $70 \%$ of original form is lost. The swelling test gives the amo-

※ Defined by the Japanese National Railways. 
地すべり Vol. 18, No. 4 (1982)

Table 2. Physical Properties of Rocks

\begin{tabular}{|c|c|c|c|c|c|}
\hline Formation & Rock & $\begin{array}{l}\text { Sampling } \\
\text { locality }\end{array}$ & $\begin{array}{l}\text { Immersion } \\
\text { test }\end{array}$ & $\underset{(\%)}{\text { Swelling text }}$ & $\begin{array}{l}\text { Unconfined compre- } \\
\text { ssive strength } \\
\left(\mathrm{kg} / \mathrm{cm}^{2}\right)\end{array}$ \\
\hline \multirow[t]{13}{*}{ Nadachi formation } & Mudstone & Nadachi tunnel & B & 1.0 & 126.0 \\
\hline & Siltstone & " & A & 1.0 & 66.3 \\
\hline & " & " & $\mathrm{C}$ & 1.0 & 23.3 \\
\hline & Mudstone & " & A & 5.5 & 5.2 \\
\hline & Siltstone & " & B & 1.0 & 24.2 \\
\hline & " & " & A & 1.0 & 30.4 \\
\hline & " & " & $\mathrm{C}$ & 1.0 & 30.6 \\
\hline & " & " & A & 1.0 & 20.8 \\
\hline & " & $" \prime$ & B & 1.0 & 7.8 \\
\hline & $"$ & $"$ & A & 1.0 & 13.3 \\
\hline & $" \prime$ & " & A & 1.0 & 41.0 \\
\hline & $"$ & " & A & 1.0 & 23.7 \\
\hline & " & " & A & 1.0 & 28.5 \\
\hline \multirow[t]{8}{*}{ Nōdani formation } & $\prime \prime$ & Kubiki tunnel & A & 1.0 & 34.0 \\
\hline & Mudstone & $" \prime$ & D & 2.6 & 25.1 \\
\hline & Siltstone & " & D & 2.8 & 41.8 \\
\hline & Black mudstone & " & D & 2.0 & 20.2 \\
\hline & Mudstone & " & $\mathrm{D}$ & 2.1 & 27.9 \\
\hline & $" \prime$ & " & C & 1.3 & 35.9 \\
\hline & " & $" 1$ & D & 2.1 & 33.4 \\
\hline & " & $"$ & C & 1.2 & 42.5 \\
\hline
\end{tabular}

(Data of 1970 by Railway Technical Research Institute, Japanese National Railways)

\begin{tabular}{|c|c|c|c|c|c|c|c|c|}
\hline \multirow{2}{*}{$\begin{array}{l}\text { Formation name } \\
\text { Montmorillonite }\end{array}$} & KawazumeF. & \multicolumn{2}{|c|}{ Nōdani $F$. } & \multicolumn{2}{|c|}{ Nishihiyama F. } & \multicolumn{3}{|c|}{ Hiuchiyama $\mathrm{F}$. } \\
\hline & $\mathrm{n}^{2}$ & & 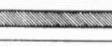 & (n) & · & & & \\
\hline Illite & & & 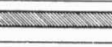 & (2) & 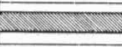 & 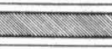 & $=$ & \\
\hline Chrolite . & 24 & $x$ & 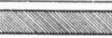 & 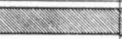 & 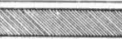 & 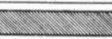 & $x^{2}$ & 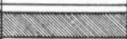 \\
\hline
\end{tabular}

Fig. 8. Clay mineral compositions of mudstone in the respective formation.

unt of swelling of the immersed sample.

As is obvious in Table 2, the values of both immersion and swelling change largely at the boundary between the Nadachi formation and the Nödani formation. The immersion test for the Nadachi formation showed that most of the samples are of $\mathrm{A}$ and $\mathrm{B}$ types and the swelling is 1.0 $\%$, whereas immersion of the Nodani formation is represented by C and D types with 2.0 to $4.0 \%$ swelling. This difference may be ascribed to the content and size distribution of montmorillonite in the mudstone.

What has been given so far is the physical and mechanical difference between the mudstone of the Nödani formation and the mudstones in other formations. The clay mineral compositions of mudstones in the respective formations are illustrated in Fig. 8. The figure shows the relative quantities of clay minerals and rock-forming minerals in the mudstone of each formation. It is seen that the clay mineral composition is markedly different from formation to formation. In other words, the clay mineral composition varies quantitatively with the stratigraphic position of the formation. An especially noticeable point is that the contents of montmorillonite, illite and chrolite are clearly discontinuous between the upper part and the lower part of the Nödani formation. Namely, the montmorillonite content of the Nödani formation shows a sudden increase from the lower part to the upper part. This turning point corresponds also to the horizon of $30 \%$ porosity, and so it will present an important problem on the geological condition for considering the kinematic picture of landslides.

Incidentally, the areal ratio of landslide occurrence to each formation is overwhelmingly larger 
in the Nödani formation than in the other formations, and landslides concentrate particularly in the upper part of the Nodani formation. This phenomenon suggests that the physico-chemical character of the mudstone constituting the Nodani formation is the fundamental cause.

To proceed with the discussion further, we must discern that with regard to the kinematic picture of such mass movements as the Koutanne landslide, the rock factors of the basement, in this case the Nodani formation, are essential as the internal condition. A supplementary explanation is given here that the mudstone in the upper part of the Nodani formation corresponds to the viscous compaction stage when judged from its porosity and other properties, and that the clay mineral composition is dominated by montmorillonite. Accordingly, the composite action of these lithologic characters accounts for the kinematic picture of the landslides. Theoretically this situation is analogous to the case of mass movement in Czechoslovakia's Handlová landslide in the area of the Neogene basement. That is to say, the mudstone of the basement must be provided with the geological condition which enables the mudstone to act as a sliding platform for the overlying solid rock mass to glide down in the form of huge blocks without being broken into small pieces.

\section{Difference between Japan and Czechoslovakia in the kinematic picture of the landslides}

It has been mentioned already that the examples of the Czechoslovakia-type kinematic picture of landslides is few in Japan. However, landslides of this type can occur in Japan if the necessary geological conditions are provided sufficiently. As represented by the landslides in Niigata Prefecture, most of the landslides of the Japanese Tertiary strata at least belong to the category of secondary and tertiary landslides. What could be the reason of such a state? This problem must be considered from the viewpoint of geological and climatic environments of the Japanese island arc and Czechoslovakia. Namely, one of the causative factors is the different climate of the two countries. The average amount of precipitation in Czechoslovakia is less than one half of that in Japan, that is, the climate of Czechoslovakia is continental. Therefore, it is assumed that Japan in the island arc and Czechoslovakia in the inland part of the continent would differ greatly in the speed, process and mechanism of rock weathering. Anothe factor is the geotectonic condition. As has been often mentioned, Czechoslovakia is a stable land except for the Carpathian mountain range, and in such a tectonic province the tectonic stress working on the rock mass that makes up a part of the crust will be much smaller than in the Japanese Islands undergoing new crustal disturbances. Accordingly, in view of the geological background the landslides in Japan are commonly of the type with slip surface having been formed in the colluvial deposit derived from detritus, without going through the process of the gliding of huge blocks which broke away from the rock mass in the natural ground. The kinematic picture of the landslides in Japan and Czechoslovakia are typically expressed as follows.

Common kinematic picture of landslides in Japan

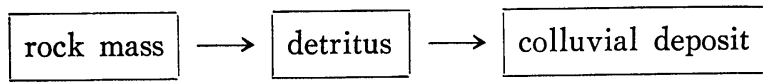

Common kinematic picture of landslides in Czechoslovakia

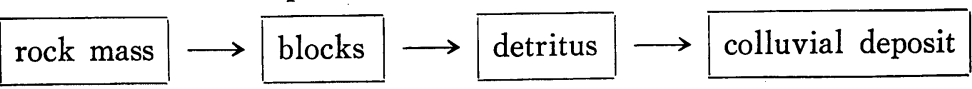

\section{Relation between the geologic province and the kinematic picture of landslides}

The writers have pointed out that the actual kinematic picture of landslide varies with geotectonic environment, and have discussed only on the case of the tectonic province of a large scale such as platform or island arc. But in the case of Japan where the tectonic province of island arc 
can be subdivided into several tectonic provinces, we have to find out whether the kinematic picture of landslide differs from province to province. This problem will be pursued next.

Uemura (1976) divided the Niigata sedimentary basin into two fold domains and a borderland between them from the geotectonic viewpoint. $\mathrm{He}$ named the area covering the Niigata plain in the north with the surrounding hilly land the Hokuetsu (northern Echigo) fold domain, and the area including the Nishikubiki district of Niigata Prefecture at the northern extremity of the Fossa Magna the Nan'etsu (southern Echigo) fold domain. The borderland is the area centering on the Higashikubiki district. Uemura's division of these three areas was based on the characteristics of folds, but geological discussion of the division will not be made here as it is beyond the object of the present paper. Nevertheless, in dealing with the kinematic picture of landslides, which is the main purport of this paper, a geotectonic side view on the basis of folding phase may be needed.

As mentioned before, the younger (Quaternary) volcanics rest on the folded Tertiary formation (Nōdani formation) with a clinounconformity in the Nan'etsu fold domain, and the volcanics are noticed to lie quite horizonta-

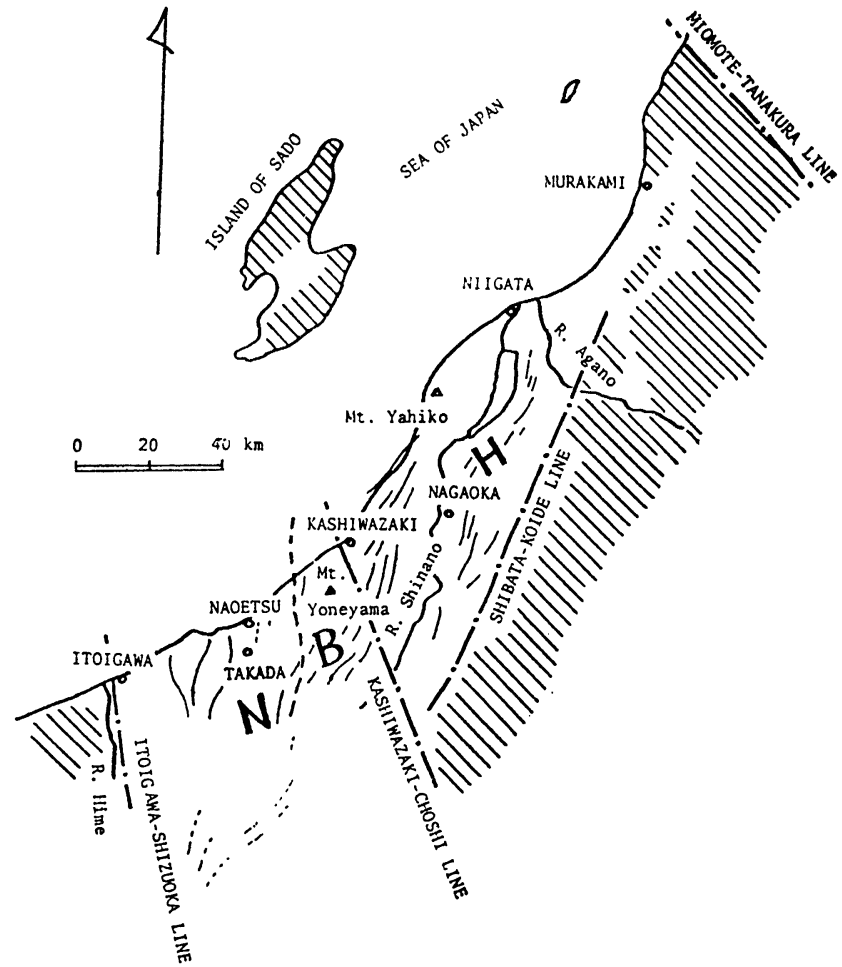

Fig. 9. Tectonic map the province of Echigo (taken from Uemura 1976). $\mathrm{H}, \mathrm{N}$, and $\mathrm{B}$ means the Hokuetsu (northern Echigo) and the Nan'etsu (southern Echigo) fold domains, and the borderland respectively.

\begin{tabular}{l||l|l|l|l} 
& MIOCENE & PLIOCENE & PLEISTOCENE & RECENT \\
\hline $\begin{array}{l}\text { HOKUETSU } \\
\text { (N. ECHIGO) }\end{array}$ & & & & \\
\hline $\begin{array}{l}\text { BORDERLAND } \\
\text { (E. KUEIKI) }\end{array}$ & & & & \\
\hline $\begin{array}{l}\text { NAN'ETSU } \\
\text { (S. ECHIGO) }\end{array}$ & & & & \\
\hline
\end{tabular}

Fig. 10. Schematic diagram showing the main phases of folding in Echigo Province(simplified from Uemura 1976).

lly. This fact suggests that in this region the crustal disturbance responsible for the fold structure had been finished prior to the accumulation of the younger volcanics. Thus, from the viewpoint of the geotectonic history it is considered that the Nan'etsu fold domain came to be a stress fleld without folding and turned into a stable region. The Hokuetsu fold domain, on the contrary, was a region affected by the island arc disturbance stronger than any other parts of the Japanese Islands, even after entering into the late Quaternary period. In this region it is found that the Uonuma formation (Quaternary) is folded too. It is supported by the fact that active folding, representing a correlation between bench mark changes and fold structure, has been lately recognized in the Hokuetsu fold domain, whereas no such movement is noticed in the Nan' etsu fold domain. In short, a large difference between the Hokuetsu fold domain and the Nan'etsu fold domain is that the former was in the stress field of horizontal compaction even during the Quaternary period while the latter became a stable region after the Quaternary period began. Therefore, we must be aware that these two tectonic provinces have undergone different processes of strain affecting the rock mass in their tectonic history. The discrete surface formed in the rock mass under such tectono- 
mechanical environments would differ qualitatively and quantitatively between the Hokuetsu fold domain and the Nan'etsu fold domain. In a stable tectonic province such as the Nishikubiki district, the development of discrete surface in the rock mass is supposed to be regular and simple, and the distribution frequency small. This may account for the formation of huge blocks observed in the Koutanne landslide.

Therefore, such mass movements as to be called Rock city in Czechoslovakia can be developed in the stress field of the Japanese island arc if the environment is tectonically stable. But another geological condition is also essential, that is, as exemplified in Czechoslovakia the physico-chemical character of the basement mudstone in the landslide area is the indispensable factor. We should realize the fact that the Czechoslovakia-type mass movement occurred in the Nishikubiki district of Niigata Prefecture but only in the area where the basement is composed of mudstone of the Nodani formation. The writers propose here that two elements, namely geologic structure and lithology (rock factors), are the essential and sufficient conditions for causing the mass movement in this case.

\section{Acknowledgements}

Professor Takeshi Uemura of Niigata University has given us the continued and most pertinent guidance from the standpoint of geomechanics throughout the present study. The valuable suggestion by Professor Karyu Tsuda of the same University has motivated us to prepare this paper. Our deep sense of gratitude is hereby expressed to the two Professors.

\section{References}

1) FUGITA, Y. (1970): Crustal movements around island-arcs in northwest Pacific since late Cretaceous, Island Arc and Ocean, (Editors by Hoshino, M. and Aoki, H.) p. 1-30, Tokai Univ. Press, Tokyo (in Japanese with English abstract).

2) HOSHINO, K. and INAMI, K. (1977): Stages of compaction as defined from change of mechanical properties, Jour. Japanese Asso. Petrol. Tech., Vol. 42, No. 2, p. 22-31 (in Japanese with English abstract).

3) IAEG (1977): Landslides and other mass movements in the Carpathian region, Guide to the postsymposium excursion, Symposium IAEG, 93p, Prague.

4) MALGT, J. and OTEPKA, J. (1977): Gravitational slope deformation near Handlova, Bull. IAEG, No. 15, p. 63-65.

5) MAHR, T. and MALGOT, J. (1977): Influence of soil physio-mechanical properties on the landslides development, Proceeding of 5th Danube European Conference Soil Mechanics Foundation Engineering, p. 211224, Bratislava.

6) NAKAMURA, H. (1976): Some problems of the landslide in Czechoslovakia and Austoria, Jour. Japan Soc. Landslide, Vol.12, No.4, p. 2-10, (in Japanese).

7) NISHIDA, S., TSUDA, K. and ICHIMURA, R. (1974): On the Neogene Tertiary in the northern part of the Fossa Magna region (Part 1), Geol. Surv. Japan Special Report, No. 250, p. 155-168 (in Japanese with English abstract).

8) NISHIDA, S. and IWAMATSU, A. (1976): A studay on the landslides in the northern part of Fossa Ma gna region, Japan, Research Report of Special Project on Japanese Natural Disasters in 1975, “Studies on the prediction and mechanisms of slope failure in northern Fossa Magna region,, p.1-13 (in Japanese).

9) NISHIDA, S. and TERAKAWA, T. (1979): Comparative study on some mass movements in Japan and Czechoslovakia, Jour. Coll. Eng. Nihon Univ., Ser. A, Vol. 21, p. 17-27 (in Japanese with English abstract).

10) UEMURA, T. (1976): Tectonic division of the Tertiary folds in the province of Echigo, central Japan, Contrbs. Geol. Mineral. Fac. Sci. Niigata Univ., No.4, p.151-157 (in Japanese with English abstract).

11) UEMURA, T. et al (1979): Quaternary fold just found along the Shibumi-gawa river, Earth Science (Chikyu Kagaku), Vol. 33, No. 2, cover page (in Japanese).

12) ZARBA, Q. anc MENCL, V. (1969): Landslides and their control, 205p Academica, Publishing House of the Czechoslovakia Academy of Science, Prague. 